\title{
Kemampuan Berpikir Kritis Siswa dalam Memahami Masalah Matematika Materi Fungsi
}

\author{
Muhammad Salahuddin ${ }^{1}$, Syahrir $^{2}$ \\ Pendidikan Matematika, STKIP Harapan Bima \\ Syahrirmandala85@gmail.com
}

\begin{abstract}
Abstrak: Penelitian ini bertujuan mendeskripsikan kemampuan berpikir kritis siswa dalam memahami masalah matematika materi fungsi. Instrumen penelitian yang digunakan adalah lembar pengamatan kemampuan berpikir kritis siswa dalam memecahkan masalah. Teknik pengumpulan data dilakukan dengan cara pemberian soal tes. Hasil penelitian menunjukan bahwa S1 dan S2 belum memenuhi ke empat kriteria berpikir kritis sehingga bisa dikatakan bahwa S1 dan S2 belum berpikir kritis.
\end{abstract}

Kata kunci : Berpikir Kritis, Pemahaman, Fungsi

\section{LATAR BELAKANG}

Salah satu tujuan pembelajaran matematika di era globalisasi sekarang adalah mendorong siswa untuk mampu berpikir kritis. Su, Ricci, \& Mnatsakanian (2016) menyatakan bahwa dalam meningkatkan kreatifitas memecahkan masalah siswa dibutuhkan kemampuan berpikir kritis karena kemampuan berpikir kritis dapat mendorong siswa untuk mencari strategi baru ketika memecahkan masalah matematika dalam mencapai tujuan pembelajaran matematika. Zetriuslita, Ariawan, \& Nufus (2016) siswa membutuhkan kemampuan berpikir kritis untuk memecahkan masalah dengan baik karena berpikir kritis dapat membantu siswa dalam memecahkan masalah untuk mencapai salah satu tujuan pembelajaran matematika. Oleh karena itu kemampuan yang sangat berperan penting dalam memecahkan masalah matematika matematika dalam mencapai tujuan pembelajaran matematika adalah kemampuan berpikir kritis.

Berpikir kritis menurut Jonshon (2009) adalah kemampuan berpikir yang jelas dan terfokus yang digunakan dalam kegiatan mental seperti pemecahan masalah, membuat keputusan, menganalisis asumsi dan melakukan penelitian secara ilmiah. Berpikir kritis menurut Ennis (1996) adalah cara berpikir reflektif berdasarkan nalar yang masuk akal dan difokuskan untuk menentukan apa yang harus diyakini dan dilakukan. Dari uraian di atas dapat di simpulkan bahwa berpikir kritis merupakan seperangkat keterampilan berdasarkan nalar dalam memahami dan memaknai masalah yang memungkinkan seseorang untuk memecahkan masalah dan membuat alternatif penyelesaian masalah.

Ennis (1996) mengemukakan terdapat 6 kemampuan dasar dalam berpikir kritis yaitu focus, reason, inference, situation, clarity, overview. Proses berpikir kritis secara umum oleh Ennis dapat dimulai dari focus dan berakhir di overview dan dilakukan dengan melalui keenam elemen tersebut secara bolakbalik. Zetriuslita dkk., (2016) menyatakan manfaat dari berpikir kritis dapat mendukung kemampuan belajar siswa dan mampu memanfaatkan kemampuan individu secara maksimal untuk dapat berkontribusi kreatif dan dapat dirasakan seumur hidup.

Kemampuan mental yang dapat membantu siswa dalam mengembangkan berpikir kritis salah satunya adalah pemahaman, bagaimana membuat keputusan dalam menyelesaikan masalah matematika. Penyelesaian suatu masalah dapat mengandalkan kemampuan pemahaman. Seperti yang diungkapkan oleh Mastie dan Johson ( dalam Wanhar, 2000) menyatakan bahwa ketika siswa dapat mengenali, menjelaskan dan menginterpretasikan suatu 
masalah disebut pemahaman. Pemahaman juga sangat diperlukan memecahkan suatu masalah matematika. Sumarmo (2003) mengungkapkan bahwa dalam menyelesaikan suatu masalah matemtika diperlukan dan masalah kehidupan sehri - hari diperlukan pemahaman matematis.

Salah satu mata dalam standar isi pelajaran matematika yang diajarkan pada SMP dan Mts adalah materi fungsi. Menurut NCTM (2000) menyatakan bahwa fungsi kuadrat termasuk dalam standar isi matematika sekolah. Kalchman \& Koedinger (2005) menyatakan bahwa fungsi dalam pendidikan matematika memiliki interpretasi yang luas tidak hanya definisi formal tetapi juga dapat dituliskan dengan banyak cara dan dideskripsikan. Lanjut Kalchman \& Koedinger (2005) menyatakan bahwa fungsi berada disekitar kehidupan kita, meskipun kita tidak menyadarinnya.

Penelitian ini bertujuan mendeskripsikan kemampuan berpikir kritis siswa dalam memahami masalah matematika materi fungsi.

\section{METODE PENELITIAN}

Subjek penelitian ini adalah siswa kelas $\mathrm{X}$ di salah satu sekolah di Kabupaten Bima, siswa yang dipilih adalah siswa dengan kemampuan baik, materi yang digunakan dalam penelitian ini adalah fungsi dengan prosedur penelitian deskriptif kualitatif yang bertujuan untuk mendeskripsikan kemampuan berpikir kritis siswa dalam memahi masalah matematika materi fungsi. Penelitian ini dilaksanakan tanggal 10 April 2020 dengan melalui sistem online. Instrumen penelitian yang digunakan adalah lembar pengamatan kemampuan berpikir kritis siswa dalam memahami masalah matematika materi fungsi. Data penelitian diperoleh melalui pemberian soal tes yang dilakukan pada kedua siswa yang dipilih sebagai subjek penelitian. Adapun soal tes fungsi yang digunakan dalam penelitian ini dapat dilihat pada gambar 1 berikut.
Kerjakan soal di bawah ini dengan tepat!

Diketahui $f, g$ dan $h$ adalah fungsi yang didefinisikan sebagai berikut.

$$
\begin{gathered}
f(x)=\sqrt{x^{2}} \\
g(x)=\sqrt{x \cdot x} \\
h(x)=|x|
\end{gathered}
$$

Apakah $f=g=h$ ? Berikan alasanmu!

\section{Gambar 1 soal tes materi fungsi}

Setalah hasil tes diperoleh dari subjek penelitian maka dilakukan analisis data penelitian dilakukan dengan cara diantaranya,

\begin{tabular}{|c|c|}
\hline $\begin{array}{l}\text { Kriteria } \\
\text { Kritis }\end{array}$ & Indikator \\
\hline Foculs & $\begin{array}{l}\text { - Siswa mampu memfokuskan pemikiran, } \\
\text { menggambarkan poin - poin utama, isu, pertanyaan, } \\
\text { atau permasalahan. } \\
\text { - Siswa mampu menuangkan hal - hal pokok yang } \\
\text { dituangkan di dalam argumen dan pada akhimya } \\
\text { didapat kesimpulan dari suatu isu, pertanyaan, atau } \\
\text { permasalahan tersebut. }\end{array}$ \\
\hline Reason & $\begin{array}{l}\text { - Siswa menyelesaikan masalah dengan langkah - } \\
\text { langkah yang tepat dan benar. }\end{array}$ \\
\hline Inference & $\begin{array}{l}\text { - Siswa membuat kesimpulan dengan tepat } \\
\text { - Siswa memilih reason (R) yang tepat untuk } \\
\text { mendukung kesimpulan yang dibuat }\end{array}$ \\
\hline Situation & $\begin{array}{l}\text { - Siswa menggunakan semua informasi yang sesuai } \\
\text { dengan permsalahan }\end{array}$ \\
\hline
\end{tabular}
dapat dilihat paada tabel dibawah ini:

Tabel 1 kriteria kemampuan berpikir kritis

sumber: Ennis (1995)

Subjek di ambil berdasarkan hasil observasi awal dengan siswa berkemampuan baik dan bedasarkan saran dari guru matematika sekolah tersebut.

\section{HASIL DAN PEMBAHASAN}

Hasil kemampuan berpikir kritis siswa sebagai subjek 1 (S1) dan subjek 2 (S2) dalam memahami masalah matematika materi fungsi

Adapun tahapan - tahapan kemampuan berpikir kritis siswa dalam memecahkan masalah latihan soal buku teks Singapura pada materi fungsi yang dilakukan oleh S1 dan S2 antara lain:

\section{Kriteria kemampuan focus}

Kemampuan berpikir kritis pada kriteria focus dapat diketahui dari hasil pekerjaan siswa dalam mengidentifikasi dan menuliskan hal hal yang penting dalam soal dan menuliskannya dengan bahasa sendiri seperti yang ditanyakan 
dan hal - hal yang diketahui pada soal. Adapun hasil pekerjaan siswa dalam mengidenfikasi dan menuliskan poin - poin penting dapat di lihat pada gambar 2 dan gambar 3

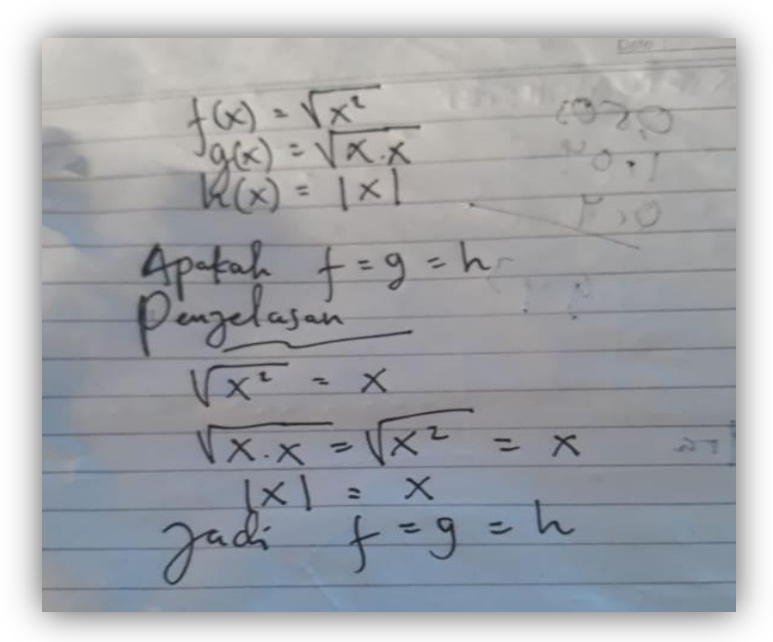

Gambar 2. Hasil pekerjaan S1 pada kriteria focus

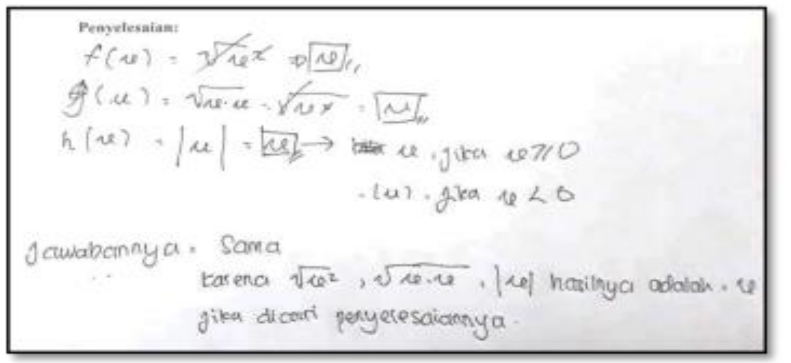

Gambar 3. Hasil pekerjaan S2 pada kriteria focus

Hasil analisis kemampuan siswa pada kriteria fokus menunjukan bahwa siswa kurang baik dalam menggambarkan poin - poin utama, isu, pertanyaan, atau permasalahan dan juga kurang baik dalam menuangkan hal - hal pokok yang dituangkan di dalam argumennya sendiri sehingga dapat disimpulkan siswa S1 kurang baik dalam kemampuan pada kriteria focus. Begitu juga dengan hasil jawaban S2, S2 sudah bisa menuliskan poin - poin penting seperti masalah pada soal dan apa yang ditanyakan, tetapi S2 langsung menuliskan jawaban tanpa memperhatikan poin - poin utama yang berupa pertanyaan, hal - hal yang penting yang perlu digunakan dalam penyelesaian soal. Dari hasil analisis tersebut sehingga peneliti dapat menyimpulkan siswa S2 dalam kemampuan berpikir kritis belum melakukan kriteria focus. Dapat disimpukan bahwa S1 maupun S2 kurang memperhatikan hal - hal yang penting dalam soal yang dapat membantu dalam penyelesaian masalah dalam soal.

Pada kriteria focus dapat diketahui dari jawaban siswa dapat mengidentifikasi atau menuliskan poin-poin penting dari soal seperti yang diketahui dan yang ditanyakan dengan menggunakan bahasanya sendiri. S1 dan S2 dalam mengidentifikasi maupun menuliskan yang diketahui dan ditanyakan dari masalah yang ada pada soal masih kurang lengkap. Hasil penelitian Newman (2008) sejumlah besar bukti bahwa anak-anak mengalami kesulitan mengidentifikasi struktur pernyataan, kosa kata, dan simbol matematika dibandingkan dengan algoritma standar. Begitu juga hasil penelitian White (2010) bahwa dalam beberapa studi yang dilakukan Newman di sekolah- sekolah, kesalahan terbesar yang dilakukan oleh siswa sekitar 70 persen adalah pada soal matematika yang khusus berada di tingkat memahami atau transformasi soal.

\section{Kriteria kemampuan reason}

Kemampuan bepikir kritis pada kriteria reason dapat diketahui informasinya dari hasil pekerjaan siswa dalam menyelesaikan masalah dengan langkah - langkah yang benar dan tepat dan membuat alasan yang masuk akal pada setiap langkah - langkah yang sesuai dengan situasi masalah dan dapat diterima untuk mendukung kesimpulan yang dibuat. Berikut hasil pekerjaan siswa pada kriteria reason dapat dilihat pada gambar 4 dan gambar 5 .

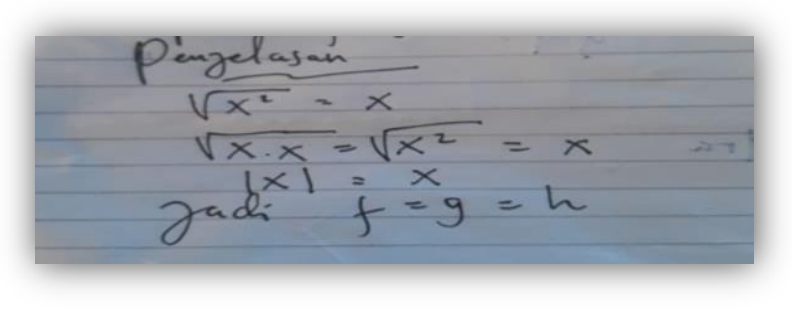

Gambar 4. Hasil pekerjan S1 pada kriteria reason 
Jurnal Ilmiah Mandala Education

http://ejournal.mandalanursa.org/index.php/JIME/index

terakreditasi Peringkat 4 (No. SK: 36/E/KPT/2019)

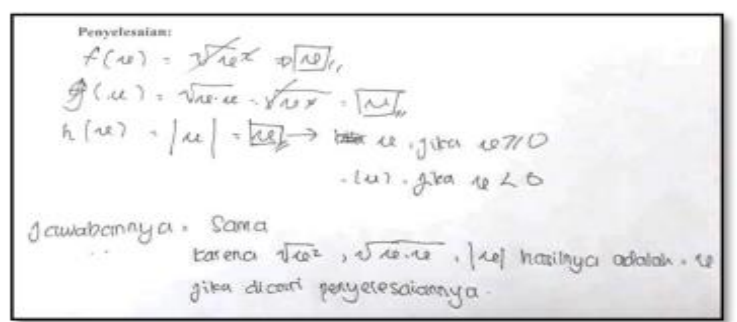

Gambar 5. Hasil pekerjaan S2 pada kriteria reason

Hasil analisis kemampuan siswa pada kriteria reason menunjukan bahwa $\mathrm{S} 1$ maupun S2 dalam menyelesaikan masalah yang diberikan tidak terlalu memperhatikan redaksi soal serta tidak memperhatikan hal - hal yang penting yang akan digunakan dalam penyelesaian masalah, sehingga S1 dan S2 langsung menyelesaikan berdasarkan pegetahuan penyelesaian bentuk aljabarnya saja tanpa memperhatikan bahwa masalah yang berikan adalah masalah fungsi. Dari hasil analisis tersebut sehingga dapat disimpulkan siswa S1 kurang dalam kemampuan pada kriteria reason. Dari hasil analisis tersebut sehingga peneliti dapat menyimpulkan siswa S2 dalam kemampuan berpikir kritis belum melakukan kriteria reason.

Kemampuan pada pada kriteria reason dapat diketahui dari informasi hasil pekerjaan siswa dalam menyelesaikan masalah dengan langkah - langkah yang benar berdasarkan penyelesaian aljabar dan kurang memperhaikan bahwa masalah yang diberikan merupakan masalah fungsi. Berdasarkan hasil analisis jawaban S1 dan S2 didapat bahwa langkah langkah dalam menyelesaikan masalah serta jawaban yang dihasilkan benar tetapi kurang benar karena hanya menyelesaikan bentuk aljabarnya tanpa memperhatikan permsalahan yang diberikan. Soedjadi (dalam Saleh, 2007) menyatakan bahwa penyebab kesulitan siswa menyelesaikan masalah bisa bersumber dari dalam diri siswa dan juga dari luar diri siswa, misalnya pengetahuan awal siswa dan pembelajaran yang kurang efektif.
Vol. 6. No. 1. April 2020

p-ISSN: 2442-9511 e-ISSN: 2656-5862

\section{Kriteria kemampuan inference}

Kemampuan berpikir kritis pada kriteria inference dapat diperoleh informasinya dari hasil pekerjaan siswa dalam membuat kesimpulan yang logis dan masuk akal dan kesimpulan sesuai dengan permintaan soal. Hasil pekerjaan siswa pada kriteria inference dapat dilihat pada gambar 6 dan 7 .

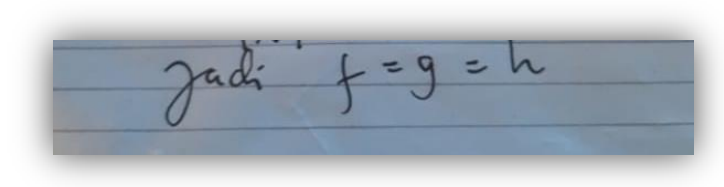

Gambar 6. Hasil pekerjaan S1 pada kriteria inference

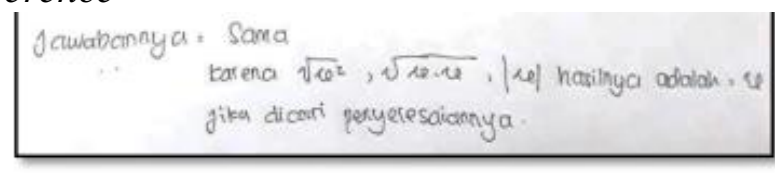

Gambar 7. Hasil pekerjaan S2 pada kriteria inference

Kemampuan siswa pada kriteria inference menunjukan bahwa siswa dalam menulis kesimpulan berdasarkan hasil penyelesaian aljabar, tidak dalam penyelesaian bantuk fungsi. Sehingga kesimpulan dari S1 dan S2 sama sama memberikan kesimpulan aljabr dan bukan kesimpulan penyelesaian fungsi. S1 dan S2 belum menunjukan kemampuan kriteria inference

Kemampuan pada kriteria inference dapat diperoleh informasinya dari hasil pekerjaan siswa dalam membuat kesimpulan yang logis dan masuk akal dan kesimpulan sesuai dengan permintaan soal. Bedasarkan hasil analisis bahwa S1 menarik kesimpulan dengan benar dan sesuai dengan permintaan dari soal berupa bentuk pola yang terbentuk dan nama pola yang terbentuk, seperti yang diungkapkan oleh Agustin (2016) bahwa siswa pada langkah penyelesaiannya dapat menarik kesimpulan yang logis dengan memberikan alasan yang masuk akal sedangkan S2 dalam membuat kesimpulan berupa bentuk pola sudah benar dan kekurangannya pada nama pola yang terbentuk.

\section{Kriteria kemampuan situation}

Kemampuan siswa pada kriteria situation menunjukan bahwa S1 dan S2 belum bisa menuliskan ataupun memahami dengan baik 
Jurnal Ilmiah Mandala Education

http://ejournal.mandalanursa.org/index.php/JIME/index

terakreditasi Peringkat 4 (No. SK: 36/E/KPT/2019)

bantuk permasalahan ataupun redaksi soal, hal ini dapat diperhatikan dari kemampuan S1 dan S2 pada kriteria focus belum bisa memaknai bentuk soal ataupun redaksi soal sehingga penyelesaian masalah S1 maupun S2 masih kurang.

Kemampuan pada kriteria situation dapat diketahui dari siswa dalam menggunakan semua informasi penting berupa diketahui dan ditanyakan sesuai dengan permasalahan pada soal, serta memahami relevansi antara alasan dan kesimpulan yang telah dibuat pada soal yang diberikan. S1 dan S2 masih belum bisa dalam mengidentifikasi informasi penting yang berupa diketahui dan ditanyakan relevansi kesimpulan yang dibuat antara S1 sudah benar tetapi S2 masih kurang dalam membuat kesimpulan. Hal ini di dukung pendapat oleh Sepeng, Percy, \& Sigola (2013) menyatakan bahwa kesulitan yang dialami siswa dalam membaca dan memahami masalah yang berupa bahasa matematis.

\section{SIMPULAN}

Berdasarkan hasil dan pembahasan dapat diambil kesimpulan bahwa kemampuan berpikir kritis siswa dalam memahami masalah matematika materi fungsi antara lain S1 dan S2 belum bisa mengidentifikasi hal - hal yang penting dalam soal berupa hal - hal yang mendsari yang harus diketahui pada materi fungsi adalah domain ( daerah asal) dan kodomain (daerah lawan) serta range ( daerah hasil) yang dihasilkan dari memasangkan domain ke kodomain. Dari hasil indentifikasi peneliti jawaban dari permasalahan yang diberikan baik S1 maupun S2 tidak terlalu memahami permasalahan yang diberikan, hal ini dapat dikeahu bahwa S1 dan S2 langsung menuliskan hasil jawaban bantuk aljabar dari soal yang berikan tanpa memperhatikan bahwa bantuk soal yang diberikan merupakan bentuk soal fungsi, dimana suatu fungsi yang yang mendasarinya adalah domain dan kodomain. Dari permasalahan fungsi yang diberikan tidak diketahui daerah pemetaan dari ketiga bentuk permasalahan yang berikan sehingga redaksi soal yang diberikan masih kurang. Hal ini
Vol. 6. No. 1. April 2020

p-ISSN: 2442-9511 e-ISSN: 2656-5862

memang disengaja oleh peneliti membuat redaksi soal yang kurang dengan tujuan apakah siswa dapat memfokuskan dan menelaah masalah bahwa bantuk masalah yang diberikan tidak bisa diselesaikan dikarenakan informasi yang terdapat pada soal masih kurang lengkap dan dapat diselesaikan apa tidak, tetapi dari hasil yang didapat siswa tidak terlalu memperhatikan bantuk soal, ataupun siswa tidak memahami bentuk soal tersebut. Sehingga bisa disimpulkan bahwa S1 dan S2 masih kurang dalam berpikir kritis.

\section{SARAN}

Adapun saran - saran yang dapat diberikan oleh peneliti yang berkaitan hasil dan pembahasan bahwa S1 dan S2 terlalu memperhatikan bentuk soal maupun kurang memahami soal yang diberikan, oleh karena itu guru dapat mengarahkan bahwa siswa seharusnya membaca dengan baik soal dan permasalah serta menidentifikasi hal - hal yang penting serta memndorong siswa untuk melihat kembali jawabannya dari awal hingga akhir apakah ada kekurangan dari jawaban tersebut atau tidak.

\section{DAFTAR PUSTAKA}

Agustin, R. D. (2016). Kemampuan Penalaran Matematika Mahasiswa Melalui Pendekatan Problem Solving. Jurnal PEDAGOGIA, 5, 179-188.

Anghileri, J. (2006). Scaffolding Practices That Enhance Mathematics Learning. Journal of Mathematics Teacher Education, 9(1), 33-52.

Ennis, R. H. (1996). Chritical Thinking. New Jersey: Printice-Hall Inc.

Hamalik, O. (2011). Kurikulum dan Pembelajaran. Jakarta: PT Bumi Aksara.

Heong, Y. M., Othman, W. B., Yunos, J. B. M., Kiong, T. T., Hassan, R. B., \& Mohamad, M. M. B. (2011). The Level of Marzano Higher Order Thinking Skills among Technical Education Students. 1(2), 121125.

Jonshon, E. (2009). Contextual Teaching and Learning. Mizan Media Utama. 
Muslich, M. (2010). Textbook Writing: Dasar dasar Pemahaman Penulisan dan Pemakaian Buku Teks. Malang: Arruzzmedia.

Newman, M. A. (2008). An analysis of sixthgrade pupils' errors on written mathematical tasks. Victorian Institute for Educational Research Bulletin, 39, 3143.

OECD. (2016). PISA 2015 Result (volume I): Excellence and Equity in Education. Paris: PISA: OECD Publishing.

Saleh. (2007). Pembelajaran Matematika Realistik untuk Topik Persegipanjang dan Persegi di Kelas VII SMP Negeri Kendari. Jurnal Ilmu Pendidikan, 2(2).

Sepeng, Percy, \& Sigola, S. (2013). Making Sense of Errors Made by Learners in Mathematical Word Problem Solving. Mediterranean Journal of Social Sciences, 4(13), 325-333.

Su, H. F. H., Ricci, F. A., \& Mnatsakanian, M. (2016). Mathematical Teaching Strategies: Pathways to Critical Thinking and Metacognition. Journal of Research in Education and Science, 2(1), 190-200.

White, A. L. (2010). Numeracy, Literacy and Newman's Error Analysis. Journal of Science and Mathematics Education in Southeast Asia, 33(2), 129 - 148.

Winarni, Setyo, E., \& Harmini, S. (2011). Matematika untuk PGSD. Bandung: PT Remaja Rosdakarya.

Wu, M. (2009). A Critical Comparison of the Content of PISA and TIMSS Mathematic Assesments. Melbourne: Faculty of Education.

Zetriuslita, Ariawan, R., \& Nufus, H. (2016). Students' Critical Thinking Ability: Description Based on Academic Level and Gender. Journal of Education and Practice, 7(12), 154-164 